\title{
Scientific Argumentation in Chemistry Education: Implications and Suggestions
}

\author{
Lee Yeng Hong ${ }^{1} \&$ Corrienna Abdul Talib ${ }^{1}$ \\ ${ }^{1}$ Department of Educational Sciences, Mathematics and Multimedia Creative, Faculty of Education, University \\ Technology Malaysia, Johor Bahru, Malaysia \\ Correspondence: Lee Yeng Hong, Department of Educational Sciences, Mathematics and Multimedia Creative, \\ Faculty of Education, University Technology Malaysia, Johor, Malaysia. Tel: 012-736-5824. E-mail: \\ LYHHYL5@yahoo.com
}

Received: August 1, $2018 \quad$ Accepted: September 1, $2018 \quad$ Online Published: October 22, 2018

doi:10.5539/ass.v14n11p16

URL: https://doi.org/10.5539/ass.v14n11p16

\begin{abstract}
The Malaysia Education Blueprint 2012-2025 reveals the aspiration of government to prepare Malaysian children to meet the challenges of a $21^{\text {st }}$ century economy. Nonetheless, Malaysia has a long way to go to achieve this target. PISA (2015) result indicates that Malaysian students have problems in reasoning skills. To achieve the target, Educational Blueprint advocates infusion of inquiry-based instruction in classrooms for students to acquire critical thinking skill. Critical thinking skill is a $21^{\text {st }}$ century learning skill the students need to possess in today's global economy. This skill includes the ability of individual to reason effectively. Scientific argumentation is a skill to promote critical thinking of students. Being the essential element of scientific inquiry and important activity in scientific reasoning, scientific argumentation helps students to develop and refine scientific knowledge. It is imperative to implement scientific argumentation in science classrooms. The purpose of this paper aims to raise some issues, including the results of previous studies about the impact of scientific argumentation on science achievement, the rationale for focusing on monological models in the three classification of argumentation models, and address the issues about the appropriateness of Toulmin argument model (an example of monologoical models), which is prevailed in science education to promote students' scientific argumentation skills. Finally, this paper will outline some suggestions regarding implementation of Toulmin argument model to promote scientific argumentation in chemistry education.
\end{abstract}

Keywords: scientific argumentation, chemistry education, Toulmin model

\section{Introduction}

The most recent education policy, Malaysia Education Blueprint 2012-2025 has been approved by the Cabinet in 2013. The blueprint has mentioned the goal for Malaysian education quality is to be in top third of countries in terms of performance in international educational standards in less than a decade by 2025 (Ministry of Education, 2012, p. E-9). It reveals the aspiration of government to prepare Malaysian children to meet the challenges of a $21^{\text {st }}$ century economy. Nonetheless, the result from Organisation for Economic Co-operation and Development (OECD, 2016) shows that in PISA 2015 test, Malaysia's score in Science (443) is below the international and OECD average (493) (Jackson, 2016). The PISA 2015 result indicates that Malaysian students have problem in reasoning skill.

In an effort to promote this goal in education, the Educational Blueprint advocates infusion of inquiry-based instruction in classrooms for students to acquire critical thinking skill. Critical thinking skill is a $21^{\text {st }}$ century learning skill the students need to possess in today's global economy. It leads the students to sift through a substantial amount of information to plan tenable ideas for their actions. This skill includes the ability of individual to reason effectively (NEA, 2012). In science education, scientific argumentation is the main practice in this field to promote reason ability. Scientific argumentation is a process in which the learners engage themselves to propose, support, critique, refine, justify, and defend their position about issues (Llewellyn, 2013). As a result, scientific argumentation enables the learners to understand how to assess scientific knowledge and generate new knowledge.

Scientific argumentation is the essential element of scientific inquiry (Llewellyn, 2013). Previous research shows that emphasizing on scientific argumentation in inquiry instruction boost students' academic performance and 
better understanding in science subject (Walker, 2011; Hasançebi \& Günel, 2013; Demirbag \& Gunel, 2014; Celep, 2015; Demircioglu \& Ucar, 2015). Among the models of argumentation to stimulate arguments in science classrooms, Toulmin argument model is the prevailed model which has been used by many scholars' in their researches (Böttcher \& Meisert, 2011; Nussbaum, 2011; Erduran \& Jiménez-Aleixandre, 2012; Foong \& Daniel, 2012; Karişan, 2015). Despite the prevalence of Toulmin model, formal logicians question about the validity of Toulmin's scheme (Foss \& Trapp, 2002; Driver et al., 2000; Upshur \& Colak, 2003; Hitchcock \& Verheij, 2006; Fox \& Modgil, 2006; Lin \& Mintzes, 2010; Nussbaum, 2011). Besides that, some researchers report the students face difficulties to distinguish the elements in Toulmin model, especially the evidence from warrant (Lin \& Mintzes, 2010; Sampson \& Walker, 2012; Hasnunidah et al., 2015).

Toulmin (2003) views argument is field-dependent, means that the acceptability of the content in arguments depends on the subject matter. Chemical knowledge is learned at three levels of representation: macroscopic, microscopic and symbolic. These three levels are called "The Chemical Triplet" which describes the method to understand science knowledge (Johnstone, 1993; Dori \& Hameiri, 2003). Professional chemists work well inside these three types of chemical representation mode (Johnstone, 1993). Therefore the combination of this mode helps the chemistry learners acquire chemical knowledge and enrich their explanations of chemical concepts. Toulmin model is ubiquitous in science education. However, the questions about its validity and problems of distinguishing elements in this model have to be resolved. This paper resolves these questions in three ways. First, it provides a brief review of issues from previous studies that investigate the impact of scientific argumentation in science achievement. Second, it outlines the conceptual framework of three categories of argumentation model and then the taxonomy of argumentation model in order to provide an overview of advantages and limit of various argumentation models. Third, it reviews literature on the scholars' critics and comments on Toulmin model. From these reviews, the appropriateness to apply Toulmin model in science education are discussed. Fourth, arguing that the Toulmin model is field-dependent, the nature of chemistry is highlighted. Then this paper shows how chemical triangle complements with Toulmin model to facilitate chemistry learners distinguish the elements in the Toulmin model.

\section{Impact of the Natural Element of Scientific Inquiry: The Scientific Argumentation for Science Achievement}

In an ever-changing highly technical society, thinking skill is necessary for students to process vast quantities of information successfully (Robinson, 1987, cited in Kremer, 2011). To promote thinking skill, the encapsulated Education Blueprint suggests infusion of inquiry approach in classrooms. Some issues however, are arisen from that. The issues of how thinking skill is acquired, developed and performed through inquiry have to be explored.

Inquiry-based instruction is not a new pedagogical method. As early as 1910, John Dewey has recommended it into K-12 science curriculum (Dewey, 1910). Inquiry is an interactive process which provides excellent means for students to achieve the scientific concepts through conducting research investigations. This process includes formulating a question, developing a hypothesis, conducting an experiment, recording data, analyzing data, and drawing conclusions (NRC, 1996). As a result, inquiry instruction approach offers students the opportunities to think as scientists.

The impact of inquiry-based instruction on academic performance has been investigated. A number of studies (Şimşek \& Kabapinar, 2010; Ugwuadu, 2010; Witt \& Ulmer, 2010; Opara, 2011; Hussain et al., 2011; Ergül et al., 2011; Taylor \& Bilbrey, 2012; Thoron \& Myers, 2012; Njoroge et al., 2014; Abdi, 2014; Singh, 2014) reported that utilizing inquiry-based instruction in science classrooms enhance the students' academic performance. Nonetheless, there are researches are inconsistent with these findings (Wild, 2012; Miller, 2014; Wu et al., 2014; Hashim et al., 2015; Maxwell, 2015). The findings of research indicate that students' performance in science is not promoted by having them practice and participate in the inquiry-based activities.

National Research Council (NRC, 2000) articulates the five essential characteristics of inquiry-based learning environment: a) learner participates in scientifically oriented questions; b) learner answers questions based on evidence; c) learner uses evidence to formulate explanations; d) learner links explanations to scientific knowledge; and (e) learner communicates to justify their explanations. These five essential characteristics of inquiry exist in the process of scientific argumentation which is a natural element of scientific inquiry (Llewellyn, 2013). In this process, the students use critical-thinking skill to help them propose, support, critique, refine, justify, and defend their position about issues (Llewellyn, 2013). Through this process, students' scientific reasoning and scientific knowledge are developed and refined (Grooms et al., 2015). As a result, infusion of scientific argumentation is a key to determine the success of inquiry-based classrooms. Omitting it can lead to inefficiency of inquiry classroom. 
Within a conceptual framework, infusion of scientific argumentation in inquiry learning can lead to important outcomes in the science classrooms. For example, Hasançebi and Günel (2013) found that chemistry students taught with argumentation-based inquiry approach outscored in tests than those who taught with traditional teaching approach. This study, as well as related work (Demirbag \& Gunel, 2014; Demircioglu \& Ucar, 2015; Nilgün, 2015) shows that argument-based inquiry is a better approach than the conventional strategy to enhance science students' academic performance. Another benefit that argument-based inquiry learning offers are development of reasoning skills and empowers students to talk and write the language of science (Jiménez-Aleixandre \& Erduran, 2008), development of scientific attitude that enable the students to develop and support a valid conclusion with genuine evidence (Walker, 2011), and improvement of argumentation and critical thinking skills among the low and high academic ability students (Hasnunidah et al., 2015).

The above finding shows that scientific argumentation in inquiry learning involves the students to use critical thinking skill to make informed decision, thus boosting their academic performance. In spite of this meaningful talking activity promotes learning in science, Ogan-Bekiroglu and Eskin (2012) reported the argumentative activities caused gradual increase in terms of quality and quantity of arguments made by students but not the conceptual growth in conceptual knowledge. On the other hand, Aydeniz et al. (2012) attested the positive effect of scientific argumentation to improve students' quality of arguments and conceptual understanding in the topic of properties and behaviours of gases. However they found that the students' ability to make argument and knowledge did not develop at the same time. As a result, Aydeniz et al. (2012) were not sure the same effect as shown in their findings would be occurred when testing students with other topics.

\section{The Conceptual Framework of Three Categories of Argumentation Model and Taxonomy of Argumentation Model}

In recent years, scientific argumentation has attracted the most scholarly attention for how it enhances learning in science. It has been used in different areas such as proof elaboration, informal reasoning, knowledge elicitation, scientific explanation, and knowledge representation (Venville \& Dawson, 2010; Aydeniz et al., 2012; Bulgren et al., 2014; Çelik \& Kılıç, 2014; Çınar \& Bayraktar, 2014; Demirbag \& Gunel, 2014; Acar, 2015; Demircioglu \& Ucar, 2015; Hasnunidah et al., 2015; Heng et al., 2015; Chen et al., 2016; Hakyolu \& Ogan-Bekiroglu, 2016; Chen \& Looi, 2017). Many argumentation models have been developed to investigate argumentation process, for example, Toulmin model, Breton's model, Amgoud et al.'s model, etc. What argumentation model is suitable to address specific needs in a field is a question that needs to be resolved. As a guide for the researchers to select appropriate argumentation model for their fields, Bentahar et al. (2010) had proposed taxonomy of argumentation models through reviews of many important argumentation models, approaches and systems found in the literature. Bentahar et al. (2010) were then categorized the argumentation model into three categories of models: rhetorical models, dialogical models, and monological models. The conceptual framework of these three categories of argumentation models are summarized in Table 1 below:

Table 1. The conceptual framework of three categories of argumentation models

\begin{tabular}{|c|c|c|c|}
\hline Model & Rhetorical Models & Dialogical Models & Monological Models \\
\hline Structure & $\begin{array}{l}\text { Rhetorical structure of } \\
\text { arguments }\end{array}$ & $\begin{array}{l}\text { Macro structure of } \\
\text { arguments }\end{array}$ & Micro structure of arguments \\
\hline Foundation & $\begin{array}{c}\text { Audience's perception of } \\
\text { arguments }\end{array}$ & Defeasible reasoning & Arguments as tentative proofs \\
\hline Linkage & $\begin{array}{l}\text { Connecting arguments in } \\
\text { a persuasion structure }\end{array}$ & $\begin{array}{c}\text { Connecting a set of } \\
\text { arguments in a dialogical } \\
\text { structure }\end{array}$ & $\begin{array}{c}\text { Connecting a set of premises to a } \\
\text { claim at the level of each } \\
\text { argument }\end{array}$ \\
\hline
\end{tabular}

(Source from Bentahar et al., 2012)

According to Bentahar et al. (2012), the foundation of rhetorical models is emphasized on the audience's perception than on the argument itself. This type of model concerned with achieving purpose of persuading audiences by appealing them a set of beliefs, rather than general acceptability (Grasso, 2002; Besnard \& Hunter, 2008; Bentahar et al., 2012). The dialogical models lay at the foundation of in the argumentation systems the basic notion is that of a defeasible reasoning. It means that the conclusion of an argument is not conclusive as it is subject to being defeated when there is new information overturns the rule that supports the conclusion 
(Bentahar et al., 2012). Defeasible reasoning allows incomplete or inconsistent knowledge to be challenged (Pereira et al., 2015; Gazzo Castañeda et al., 2016; Ragni et al., 2017). It is often used in the logic of law (Dung \& Sartor, 2011; Gazzo Castañeda \& Knauff, 2016) and development of artificial intelligence (Pollock, 1987; Gómez et al., 2010; van Gijzel \& Prakken, 2012; van Eemeren et al., 2014; Pereira et al., 2015). This kind of model regards arguments as macro entities; the conflict resolution process is the main concern of dialogical models (Bentahar et al., 2012). A third classification of models, referred to as monological models. This kind of model focuses on the micro structure of arguments, meaning the relationship between the premises. The models built upon a foundation of the arguments are regarded as tentative proofs for propositions (Bentahar et al., 2012).

A convincing argument is first built upon the foundation of interrelation between premises and conclusions, then only taking account the relations between the other arguments which may challenge the conclusion. In some circumstances in which the arguments are produced to achieve some preplanned goals, such as the participating agents' believes, then the audience's perception has to be considered as well (Bentahar et al., 2012). It is thus a good argument includes micro, macro and rhetorical features. Among the three features of an argument (micro, macro, and rhetorical), the micro structure should be addressed at the first level. Then only the next two features are taken into account. As a result, it is important to select an appropriate monological model to produce and start good arguments. This paper compares some popular monological models, in terms of their argument structure, inference rules, advantages, and limit to provide an overview of the models and guideline for the researchers to select argumentation model that accord with the demands of their research topics.

Table 2. Comparison of the monological models (adapted from Bentahar et al., 2012)

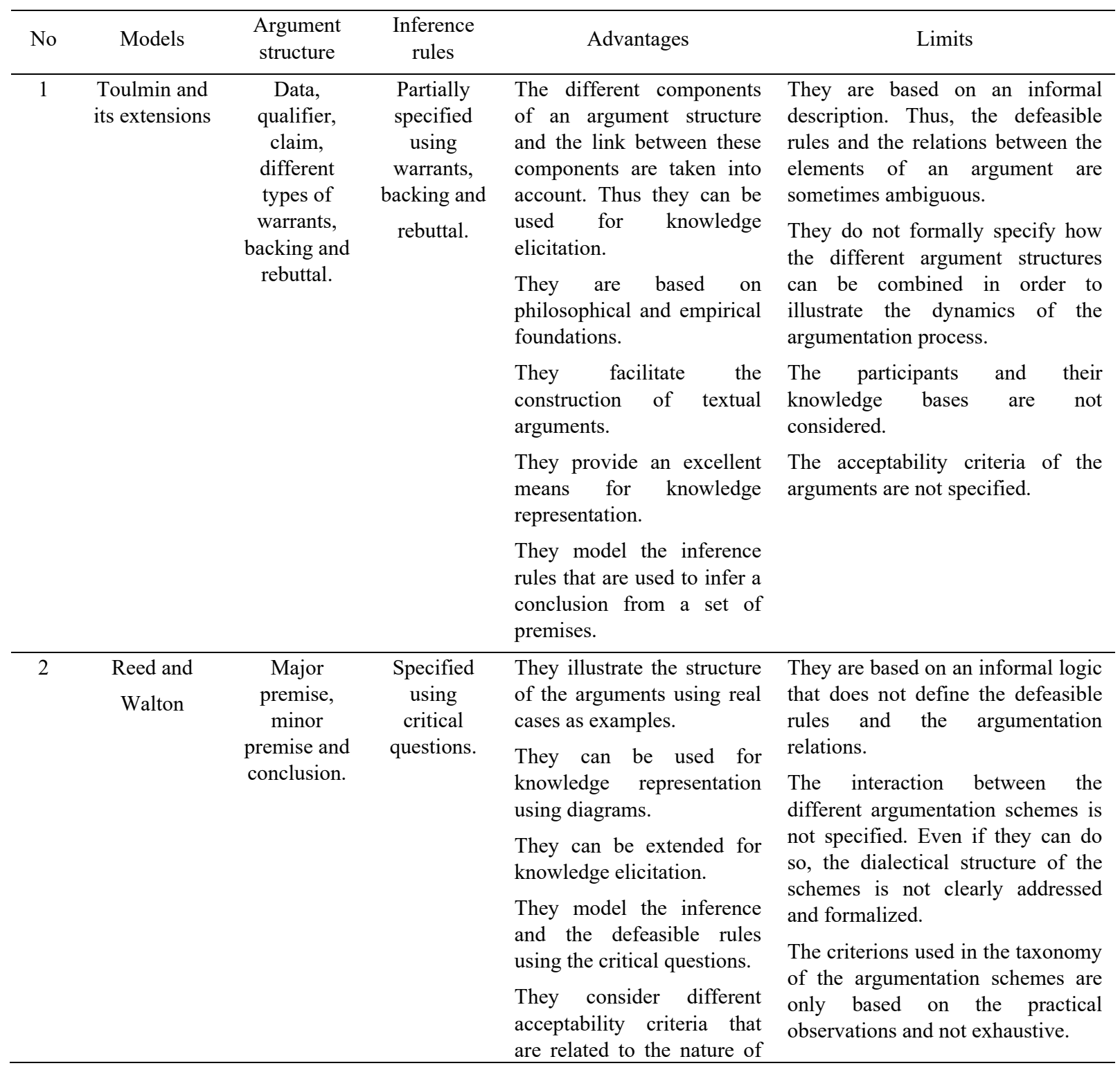




\begin{tabular}{|c|c|c|c|c|c|}
\hline & & & & the schema. & $\begin{array}{l}\text { The participants' knowledge bases } \\
\text { are not considered. }\end{array}$ \\
\hline 3 & $\begin{array}{l}\text { Anscombre } \\
\text { and Ducrot }\end{array}$ & Topoï & $\begin{array}{l}\text { Specified } \\
\text { using topos: } \\
\text { gradual } \\
\text { inference } \\
\text { rules. }\end{array}$ & $\begin{array}{l}\text { The notion of topos can be } \\
\text { used to illustrate and } \\
\text { formalize the link between } \\
\text { the premises and the } \\
\text { conclusion of an argument. } \\
\text { The approach can be used } \\
\text { to generate qualitative } \\
\text { explanations about the } \\
\text { inference rules. }\end{array}$ & $\begin{array}{l}\text { The approach is defined in an } \\
\text { informal language and the different } \\
\text { argumentation relations are not } \\
\text { defined. } \\
\text { The theoretical foundations are not } \\
\text { clearly stated. } \\
\text { It does not offer a deep mechanism } \\
\text { for knowledge representation. } \\
\text { It neglects the agents participating } \\
\text { in the argumentation game. } \\
\text { The argumentation process is not } \\
\text { illustrated. The different elements } \\
\text { are not distinguished and the } \\
\text { acceptability criterions of elements } \\
\text { are not specified. Thus it cannot be } \\
\text { used for knowledge elicitation. }\end{array}$ \\
\hline 4 & Breton & $\begin{array}{c}\text { Not } \\
\text { specified }\end{array}$ & $\begin{array}{l}\text { Specified } \\
\text { using } \\
\text { framing and } \\
\text { linkage. }\end{array}$ & $\begin{array}{l}\text { It provides a general } \\
\text { taxonomy of arguments by } \\
\text { defining the link between a } \\
\text { macro-view and a } \\
\text { micro-view of arguments } \\
\text { It models the different } \\
\text { levels in the acceptability of } \\
\text { arguments and inference } \\
\text { mechanism (Authority } \\
\text { level, Realignment, } \\
\text { deductive level and } \\
\text { analogical level). }\end{array}$ & $\begin{array}{l}\text { It does not offer any definition of } \\
\text { the argument structure and it does } \\
\text { not specify the argumentation } \\
\text { process. Consequently, this model } \\
\text { is not appropriate for knowledge } \\
\text { representation and elicitation. } \\
\text { The theoretical foundations are } \\
\text { missing. } \\
\text { It does not take into account the } \\
\text { characteristics of the participating } \\
\text { agents. }\end{array}$ \\
\hline
\end{tabular}

Table 2 shows the four examples of monological models which are usually apply in the fields of research. The Table 2 indicates that these models have their advantages and limits. As a result, there is no perfect model to promote and measure people scientific argumentation skill. How to choose an argumentation model is thus depending on whether the limits of the argumentation models can be overcome to a certain extent of acceptable limit. The basis of scientific method is all scientific knowledge must be based on observation and investigation (Kosso, 2011). Thus the monological model which is based on empirical foundation must be selected. This paper aims to suggest an argumentation model for the learning in chemistry education. Being a monological model which is built based on philosophical and empirical foundation; Toulmin model models the inference rules that are used to infer a conclusion from a set of premises is thus an excellent means for knowledge representation and knowledge elicitation. This paper suggests Toulmin model to promote scientific argumentation in chemistry learning. From the issues of applying Toulmin's model in science education and the nature of chemistry, the rationale to use apply Toulmin model is further elaborated and the ways to overcome limits of Toulmin model are suggested.

\section{Issues and Rationale to Apply Toulmin's Argument Model in Science Education}

Scientific argumentation can be used as a tool to hone critical thinking skill (Hussain et al., 2017). It is crucial for students to refine scientific knowledge (Grooms et al., 2015). The previous studies (Ogan-Bekiroglu \& Eskin, 2012; Aydeniz et al., 2012) which do not show the obvious effect of scientific argumentation are however, wondering the readers about the tangible benefit to practice scientific argumentation in classrooms. The offbeat findings may due to the process of scientific argumentation is misconducted. It is important to note that scientific argumentation involves the core feature of science that is the coordination of evidence and theory for supporting or refuting an explanatory conclusion (Suppe, 1998; Shemwell \& Furtak, 2010). As a result, incapability of students to do so may cause failure of scientific argumentation classrooms.

Among the frameworks of argumentation, Toulmin (1958) model of argumentation is broadly used in the research of science education (Böttcher \& Meisert, 2011; Nussbaum, 2011; Erduran \& Jiménez-Aleixandre, 
2012).There are six elements in Toulmin model.The three elements: claim, grounds, and warrant are primary elements present in every argument; another three elements: backing, rebuttal, and qualifier are added as necessary in arguments (Karbach, 1987). Claim is the basic purpose of an argument or assertion about an issue; data are the evidence that supports the claim; warrant links the data to the claim. It is a reason for making a claim; backing enhances the reliability of the warrant; rebuttal is valid statements that can invalidate the warrant and thus the claim; qualifier modifies the claim (Brockriede \& Ehninger, 1960; Karbach, 1987; Toulmin; 1958).



Figure 1. Toulmin (1958) argument framework

Toulmin's argumentation model describes the link between data, claim and how warrant, backing, and qualifier strengthen an argument (Toulmin, 1958; Karbach, 1987), therefore giving detailed analysis the strengths and weaknesses of an argument. In addition, Toulmin incorporates argument fields (field-dependent arguments and field-invariant arguments) to augment his framework (Schroeder, 1997). The conclusion made based on Toulmin model is thus judged by the subject matters (fields) and open to exception. Toulmin model has been applied as an educational tool to improve students' conceptual understanding and assess students' quantity and quality of arguments (Simon et al., 2006; Lin \& Mintzes, 2010; Venville \& Dawson, 2010; McNeill, 2011;Aydeniz et al., 2012; Hand et al., 2012; Ogan-Bekiroglu \& Eskin, 2012; Kaya, 2013; Walker \& Sampson, 2013; Yalçın Çelik \& Kılıç, 2014; Hasnunidahet al., 2015; Karişan, 2015; Probosari et al., 2016). Even though Toulmin model is generally accepted, it encounters different judgments from scholars.

Formal logicians question about the practical argument focus in Toulmin scheme which is proposed based on probability in a circumstance but not the truth (Foss, 2002). As a result, the validity in Toulmin model for judging argument strength is doubted (Driver et al., 2000; Upshur \& Colak, 2003; Fox \& Modgil, 2006; Hitchcock, 2006; Lin \& Mintzes, 2010; Nussbaum, 2011). Furthermore, Toulmin's idea of conclusion is judged by domain specific standards which are based on subject matters. The conclusion made according to Toulmin model is tentative. However, formal logicians focus on analytical argument. They assume the standards to judge and validate arguments are not varied across the subject matters (Foss, 2002). In making conclusion, they view a conclusion must be made from premises with absolute certainty; no further inferring occurs once information obtained is the part of premises as the information can directly bring to the conclusion (Nussbaum, 2011).

Table 3. The difference between Toulmin and formal logician in their view of the concept of an argument

\begin{tabular}{lll}
\hline & Toulmin & Formal Logician \\
\hline $\begin{array}{l}\text { Dichotomy of logos in argument } \\
\text { Criterion of the conclusion }\end{array}$ & Practical argument & Analytical argument \\
& $\begin{array}{l}\text { Based on probability in a } \\
\text { circumstance. }\end{array}$ & $\begin{array}{l}\text { Made from premises with absolute } \\
\text { certainty. }\end{array}$ \\
& $\begin{array}{l}\text { Judged by domain specific } \\
\text { standards (subject matters). }\end{array}$ & $\begin{array}{l}\text { Standards to judge arguments are the same } \\
\text { and never vary across the subject matters }\end{array}$ \\
\hline
\end{tabular}

Toulmin (1958) introduces a layout of argument scheme making an argument a more readily understandable fashion. Nonetheless, there are research have reported the difficulties of students to apply Toulmin model in making good arguments. The difficulties of students to apply this model are due to their failure to explain the reasons why evidence support the claim and is included in their arguments (Sampson \& Walker, 2012) and students are unable to develop a rebuttal based on adequate data, warrant, or backing (Hasnunidah et al., 2015). These findings indicate that students confuse about the difference between data and evidence is the main reason. Data are the information from an investigation whereas evidence is a subset of data relevant to the question being investigated for supporting or refuting a claim (Llewellyn \& Rajesh, 2011). These two terms can be 
confusing. Even the high achievers do not fully understand the meaning of evidence and mistreat warrants as evidence (Lin \& Mintzes, 2010).

Scholars pass different judgments on the Toulmin's argumentation model. Still, this model is ubiquitous and applied in current science education. To ascertain the appropriateness of Toulmin model to promote good argument in science education, the question regarding of its validity has to be resolved. For this purpose, we have to recognize the meanings of inquiry and argumentation in science. If not, our preference would lead us bias to formal logic or informal logic about argumentation. National Science Education Standards defines inquiry is an activity that require learners' ability of critical and logical thinking, and consideration of alternative explanations to make observations, examine and evaluate their proposed explanations from evidence derived from their works (NRC, 1996). Argumentation, on the other hand, is the heart of scientific inquiry (Böttcher \& Meisert, 2011), the natural element of scientific inquiry (Llewellyn, 2013) and central role to learn about science (Driver et al., 2000). As a result, the process of scientific argumentation involves justification of propositions consists of observation statements amounting to evidence and expressing standpoint in a theoretically way (Shemwell \& Furtak, 2010).

Science is not a matter of knowing universe but a method of guidelines to organize experiences for yielding predictive power (Riegler, 1998). The universe is not knowable but human continuous effort to discover it. Thus, there is no theory is permanently true but overthrown when it faces challenges and fails to explain the phenomenon occurs in its area. For example, from ancient times, people believe that once head is separated from body, human will die; people believe that electrons are orbiting around the central nucleus like Earth revolves around the Sun. However human beliefs are shaken when new knowledge is discovered by scientists. In recent years, head transplant has been a focus of study by neurosurgeon. The neurosurgeon, Sergio Canavero and Ren Xiao Ping had carried out a series of head transplant experiments on animal successfully in 2016 and, they announce the first human head transplant will be carried out in December 2017 (Osborne, 2017, April 27). In the field of quantum mechanics, Bohr's physical model of the atom and subshell assignments are proved incorrect. The electrons are not moving in circle motion but in a secondary quantum number with different shapes. Later, Bohr's electronic configuration is replaced by the secondary quantum number with the series notations (s, p, d, and f) by Friedrich Hermann Hund (Rae, 2007).

The continuous discovery of science knowledge indicates that there is no certainty in science as long as the new knowledge is still discovered. Science only provides us guidelines to organize experiences (Riegler, 1998) but not directly tell us the absolute certainty in this world nor how to use scientific knowledge. Thus it is a mistake to assume that a conclusion is made from premises with absolute certainty and no further inferring occurs. Toulmin's belief that the knowledge is not enduring (Foss, 2002), his criterion of justification is not absolute and there is argument fields in his argumentation framework. It is unquestionably his belief of practical argumentation fulfills the needs of this ever changing world; his argument framework provides people a way to learn how to think outside the box, thus achieving the breakthrough and limitations of science. Toulmin's model may not the best model to promote good argument. However, there is no research finding reports the best argument scheme for science education. If there is some limit in Toulmin's model, the limit is nothing when many scholars (Brockriede \& Ehninger; 1960; Locker \& Keene, 1983; Karbach, 1987; Hitchcock, 2006; Zarębski, 2009) prove the advantages of Toulmin's model to promote students' learning.

\section{Chemical Representation of Matter (Chemistry Triplet) and Toulmin's Model}

Toulmin (1958) views the acceptability of the content in an argument depends on the subject matter; there is a criterion there in certain field for people to judge an argument. As a branch of science, Chemistry is the study of the matter, properties, and laws that rule it (Ponce-Espinosa et al., 2014). To understand the abstract concepts in chemistry, professional chemists predominantly work inside chemical representations: macroscopic, sub-microscopic, and symbolic (Johnstone, 1993). The macroscopic level is related to any observable situation; the microscopic level related to behaviour of unseen molecular structures; the representational level records the microscopic level in the form of symbols, formulae, equations, molarity, mathematical manipulation or graphs (Johnstone, 2000). Previous researches show that the ability to interplay between chemical representations promotes students' conceptual understanding (Kirbulut \& Beeth, 2013; Yakmaci-Guzel \& Adadan, 2013; Sim \& Daniel, 2014; Milenković et al., 2016); improving their mental model (Sunyono et al, 2015) and reducing cognitive load (Milenković et al., 2014). The failure to use sub-microscopic approach to interpret and explain a phenomenon in macro-microscopic view cause insufficient construction of the scientific knowledge (Ozmen, 2011) and hence the misconception which handicaps students' learning (Kelly et al., 2010; Surif et al., 2014; Serobatse et al., 2014). As a result, the ability to operate within chemical representation is important to judge a claim in chemistry successfully. 
Previous studies (Lin \& Mintzes, 2010; Sampson \& Walker, 2012; Hasnunidah et al., 2015) show that students do not understand the meaning of evidence. They are unable to provide reasons for their evidences and support claim with observable evidence. Besides that, students, mistreat warrants as evidence. It is thus students have problems to apply Toulmin model is because they do not know the meaning of evidence and fail to distinguish evidence from warrant. In Toulmin model, all arguments begin with data or evidences that support a claim (Warren, 2010). Concept of data is essential to scientific inquiry. Although there is some similarities but the concept of data is different from evidences. Data have to be implied, it is called as evidence. If data is simply taken without interpreted, there will be no informative component in an argument (Brockriede \& Ehninger, 1960). Though evidence can be used to justify claim and support conclusion. However when the data is inconclusive, it cannot be the adjudicator of claims (Upshur \& Colak, 2003). In this case, warrants are needed to justify connection between data and claim (Driver et al., 2000). Warrant is fundamental to scientific critical reasoning. It is unspoken assumption (rules, principles, inference-licenses) which is brought to the surface through logical inference (Driver, 2000; Warren, 2010). However teaching students to identify warrant is a tough task that sometimes instructors omit warrant from argumentation framework (Warren, 2010).

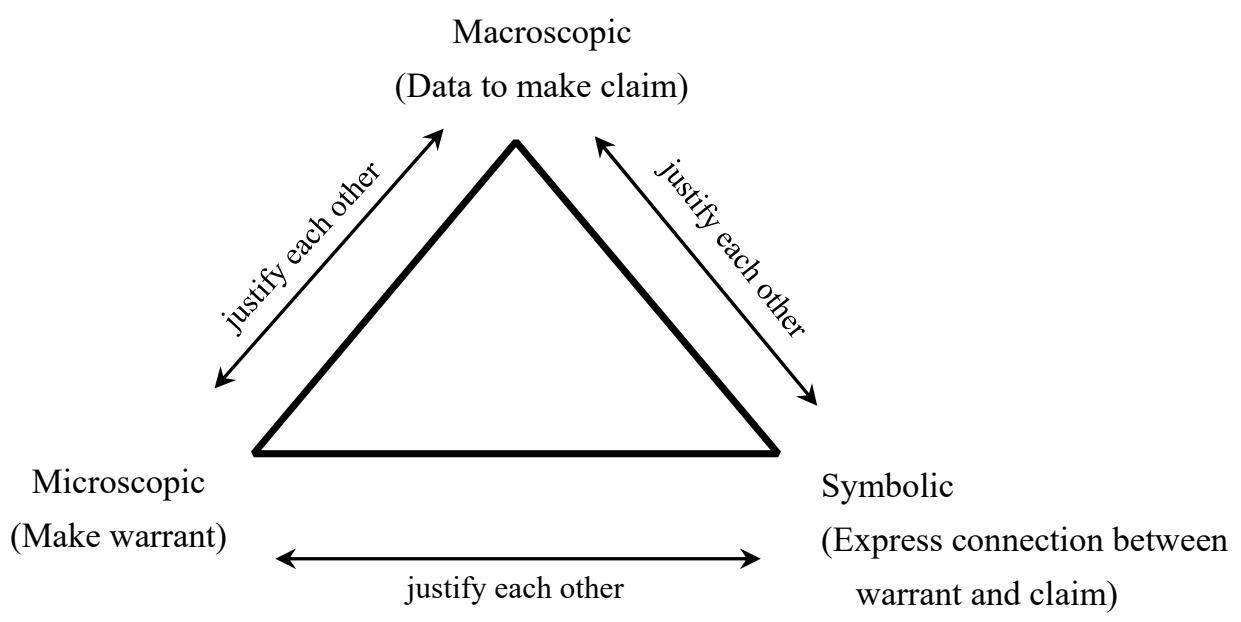

Figure 2. Incorporating Chemical triplet in Toulmin's Framework

The data is about facts and warrant is about rules (Toulmin et al., 1984). From the literature review and findings, it is found that in order to facilitate students use Toulmin's model to make good argument in chemistry, teacher has to teach students how to interpret data and relate sub-microscopic level of chemical representation in making warrant. It is believed that using the chemical triplet as a tool to judge the elements in Toulmin model helps students make good argument in chemistry.

\section{Conclusion}

Critical thinking skill is a $21^{\text {st }}$ century learning skill the students need to possess in today's global economy. Scientific argumentation is a process to hone this skill (Hussain et al., 2017). To promote this skill in science education, Toulmin's model of argumentation is broadly used (Böttcher \& Meisert, 2011; Nussbaum, 2011; Erduran \& Jiménez-Aleixandre, 2012). Nonetheless, formal logicians comments that Toulmin scheme is proposed based on probability in a circumstance (Foss, 2002), the validity to judge argument strength (Driver et al., 2000; Upshur \& Colak, 2003; Fox \& Modgil, 2006; Lin \& Mintzes, 2010; Nussbaum, 2011) is thus not convincing.

It is found that there are no study reports the best argumentation scheme for study science education. Furthermore, seeking consensus of an ideal argumentation scheme takes time or at best, results in inferior choices. The general purpose of Science aims to reach consensus between reasoning and argumentation and there are previous studies (Brockriede \& Ehninger; 1960; Locker \& Keene, 1983; Karbach, 1987; Hitchcock; 2006; Zarębski; 2009) prove the advantages of Toulmin model to promote students' learning. As a result this paper suggest Toulmin's (1958) model that is said broadly used in the study of science education (Böttcher \& Meisert, 2011; Nussbaum, 2011; Erduran \& Jiménez-Aleixandre, 2012) for chemistry education.

Toulmin et al. (1984) advocates the validity of an argument should not determine by formal logic but the ideas in an argument can survive through critical evaluation. The standard for justifying claim in an argument is premised on the assumption that different fields have different bedrocks that must be obeyed. Chemistry is the study of the 
matter, properties, and laws that rule it (Ponce-Espinosa et al., 2014). Thus the ability to work inside chemical representations: macroscopic, sub-microscopic, and symbolic is important to understand chemical concept (Johnstone, 1993). To make a claim in the topics related to chemistry, students should be able to justify their claim using the chemical triplet.

Previous studies (Lin \& Mintzes, 2010; Sampson \& Walker, 2012; Hasnunidah et al., 2015) indicate that students face difficulties to use Toulmin' model because they do not know the meaning of evidence and fail to distinguish evidence from warrant. To solve this problem, students have to know that data is about facts and warrant is about rules (Toulmin et al., 1984). They have to learn how to marshal and interpret data to obtain informative component in an argument (Brockriede \& Ehninger, 1960). If the data is informative enough, it is the evidence to justify claim and support conclusion (Upshur \& Colak, 2003). However if the data are inconclusive, warrants are needed to justify connection between data and claim (Driver et al., 2000). In this case, students have to know how to make warrant in an argument.

Warrant is unspoken assumption (rules, principles, and inference-licenses) made through logical inference (Driver, 2000; Warren, 2010). Hence, it is not easy to teach students make warrant that sometimes teachers omit warrant from argumentation framework (Warren, 2010). The microscopic level related to behaviour of substances, thus teaching students to make warrant using this level facilitate them to make warrant. Incorporation of chemical triplet in Toulmin model for chemistry learning matches with the Toulmin's concept of field dependent. It is believed that chemical triplet can be served as guideline to judge the elements in Toulmin model and help chemistry students make better arguments.

\section{References}

Abdi, A. (2014). The Effect of Inquiry-based Learning Method on Students' Academic Achievement in Science Course. Universal Journal of Educational Research, 2(1), 37-41.

Acar, O. (2015). Examination of Science Learning Equity through Argumentation and Traditional Instruction Noting Differences in Socio-Economic Status. Science Education International, 26(1), 24-41.

Aydeniz, M., Pabuccu, A., Cetin, P. S., \& Kaya, E. (2012). Argumentation and Students' Conceptual Understanding of Properties and Behaviors of Gases. International Journal of Science and Mathematics Education, 10(6), 1303-1324. https://doi.org/10.1007/s10763-012-9336-1

Bentahar, J., Moulin, B., \& Bélanger, M. (2010). A Taxonomy of Argumentation Models Used for Knowledge Representation. Artificial Intelligence Review, 33, 211-259. https://doi.org/10.1007/s10462-010-9154-1

Besnard, P., \& Hunter, A. (2008). Elements of Argumentation. Cambridge, MA, USA: MIT Press. https://doi.org/10.7551/mitpress/9780262026437.001.0001

Böttcher, F., \& Meisert, A. (2011). Argumentation in Science Education: A Model-based Framework. Science \& Education, 20, 103-140. https://doi.org/10.1007/s11191-010-9304-5

Brockriede, W., \& Ehninger, D. (1960). Toulmin on Argument: An Interpretation and Application. Quarterly Journal of Speech, 46, 44-53. https://doi.org/10.1080/00335636009382390

Bulgren, J. A., Ellis, J. D., \& Marquis, J. G. (2014). The Use and Effectiveness of an Argumentation and Evaluation Intervention in Science Classes. Journal of Science Education and Technology, 23, 82-97. https://doi.org/10.1007/s10956-013-9452-x

Celep, N. D. (2015). The Effects of Argument-Driven Inquiry Instructional Model on 10th Grade Students' Understanding of Gas Concepts. Unpublished Doctoral Degree Thesis. Faculty of Education. Middle East Technical. Retrieved from http://etd.lib.metu.edu.tr/upload/12618357/index.pdf

Çelik, A. Y., \& Kılıç, Z. (2014). The Impact of Argumentation on High School Chemistry Students' Conceptual Understanding, Attitude towards Chemistry and Argumentativeness. Eurasian Journal of Physics and Chemistry Education, 6(1), 58-75.

Chen, W., \& Looi, C. K. (2017). Measuring Process and Outcome of the Scientific Argumentation in a CSCL Environment. In W. Chen, J.-C. Yang, A. F. Mohd Ayub, S. L. Wong, \& A. Mitrovic (Eds.), Proceedings of the 25th International Conference on Computers in Education (pp. 139-145).

Chen, H. T., Wang, H. H., Lu, Y. Y., Lin, H. S., \& Hong, Z. R. (2016). Using a Modified Argument-Driven Inquiry to Promote Elementary School Students' Engagement in Learning Science and Argumentation. International J. of Science Education, 38(2), 170-191. https://doi.org/10.1080/09500693.2015.1134849

Çınar, D., \& Bayraktar, Ş. (2014). Evaluation of the Effects of Argumentation Based Science Teaching on 5th 
Grade Students' Conceptual Understanding of the Subjects Related to "Matter and Change". International J. of Education in Mathematics, Science and Technology, 2(1), 49-77. https://doi.org/10.18404/ijemst.06465

Demirbag, M., \& Gunel, M. (2014). Integrating Argument-Based Science Inquiry with Modal Representations: Impact on Science Achievement, Argumentation, and Writing Skills. Educational Sciences: Theory \& Practice, 14(1), 386-391. https://doi.org/10.12738/estp.2014.1.1632

Demircioglu, T., \& Ucar, S. (2015). Investigating the Effect of Argument-Driven Inquiry in Laboratory Instruction. Educational Sci.: Theory \& Practice, 15(1), 267-283. https://doi.org/10.12738/estp.2015.1.2324

Dewey, J. (1910). How We Think. Boston: D. C. Health \& Co. https://doi.org/10.1037/10903-000

Dori, Y. J., \& Hameiri, M. (2003). Multidimensional Analysis System for Quantitative Chemistry Problems: Symbol, Macro, Micro, and Process Aspects. Journal of Research in Science Teaching, 40(3), 278-302. https://doi.org/10.1002/tea.10077

Driver, R., Newton, P., \& Osborne, J. (2000). Establishing the Norms of Scientific Argumentation in Classrooms. Science Education, 84(3), 287-312. https://doi.org/10.1002/(SICI)1098-237X(200005)84:3<287::AIDSCE1>3.0.CO;2-A

Dung, P. M., \& Sartor, G. (2011). The Modular Logic of Private International Law. Artificial Intelligence and Law, 19, 233-261. https://doi.org/10.1007/s10506-011-9112-5

Erduran, S., \& Jimenez-Aleixandre, J. M. (2012). Argumentation in Science Education Research: Perspectives from Europe. In D. Jorde, \& J. Dillon (Eds.), Science Education Research and Practice in Europe: Retrospective and Prospective. (pp. 253-289). Rotterdam: Sense Publishers. https://doi.org/10.1007/978-94-6091-900-8_11

Ergül, R., Şimşekli, Y., Çaliş, S., Özdilek, Z., Göçmençelebi, Ş., \& Şanli, M. (2011). The Effects of Inquiry-Based Science Teaching on Elementary School Students' Science Process Skills and Science Attitudes. Bulgarian Journal of Science and Education Policy, 5(1), 48-68.

Foong, C. C., \& Daniel, E. G. S. (2012). Students' Argumentation Skills across Two Socio-Scientific Issues in a Confucian Classroom: Is transfer possible? International Journal of Science Education. https://doi.org/10.1080/09500693.2012.697209

Foss, S. K., \& Trapp, R. (2002). Stephen Toulmin. In S. K. Foss, \& R. Trapp (Eds.), Contemporary Perspectives on Rhetoric (3rd ed., pp. 117-153). Prospect Height, Illinois: Waveland Press Inc.

Fox, J., \& Modgil, S. (2006). From Arguments to Decisions: Extending the Toulmin View. In D. Hitchcock, \& B. Verheij (Eds.), Arguing on the Toulmin Model: New Essays in Argument Analysis and Evaluation (pp. 273-287). Dordrecht, The Netherlands: Springer. https://doi.org/10.1007/978-1-4020-4938-5_18

Gazzo Castañeda, L. E., \& Knauff, M. (2016). Defeasible Reasoning with Legal Conditionals. Memory and Cognition, 44, 499-517. https://doi.org/10.3758/s13421-015-0574-7

Gazzo Castañeda, L. E., Richter, B., \& Knauff, M. (2016). Negativity Bias in Defeasible Reasoning. Thinking \& Reasoning, 22(2), 209-220. https://doi.org/10.1080/13546783.2015.1117988

Gómez, S. A., Chesñevar, C. I., \& Simari, G. R. (2010). Reasoning with Inconsistent Ontologies through Argumentation. Applied Artificial Intelligence, 24, 102-148. https://doi.org/10.1080/08839510903448692

Grasso, F. (2002). Towards a Framework for Rhetorical Argumentation. Towards a framework for rhetorical argumentation. In J. Bos, M. E. Foster, \& C. Matheson (Eds.), Proceedings of the 6th Workshop on the Semantics and Pragmatics of Dialogue (EDILOG-2002) (pp. 53-60). Edinburgh, UK.

Grooms, J., Enderle, P., \& Sampson, V. (2015). Coordinating Scientific Argumentation and the Next Generation Science Standards through Argument Driven Inquiry. Summer, 24(1), 45-50.

Hakyolu, H., \& Ogan-Bekiroglu, F. (2016). Interplay between Content Knowledge and Scientific Argumentation. Eurasia Journal of Mathematics, Science \& Technology Education, 12(12), 3005-3033. https://doi.org/10.12973/eurasia.2016.02319a

Hand, B., Nam, J., \& Choi, A. (2012). Argument-Based General Chemistry Laboratory Investigations for Pre-Service Science Teachers. Quimica Education, 23, 96-100. https://doi.org/10.1016/S0187-893X(17)30141-6

Hasançebi, F. Y., \& Günel, M. (2013). Effects of Argumentation Based Inquiry Approach on Disadvantaged Students' Science Achievement. Elementary Education Online, 12(4), 1056-1073. 
Hashim, A., Sheik Ababkr, T. E., \& Eljack, N. S. A. (2015). Effects of Inquiry Based Science Teaching on Junior Secondary School Students' Academic Achievements: A Case Study in Hadejia Zonal Education Area of Jigawa State, Nigeria. SUST Journal of Humanities, 16(1), 156-169.

Hasnunidah, N., Susilo, H., Irawati, M. H., \& Sutomo, H. (2015). Improved the Discourse Pattern in Students Argumentation through the Use of Scaffolding on Strategy Argument-Driven Inquiry. Seminar Nasional XII Pendidikan Biologi (pp. 645-651). FKIP UNS.

Heng, L. L., Surif, J., Seng, C. H., \& Ibrahim, N. S. (2015). Mastery of Scientific Argumentation on the Concept of Neutralization in Chemistry: A Malaysian Perspective. Malaysian Journal of Learning and Instruction, 12(1), 85-101.

Hitchcock, D. (2006). Good Reasoning on the Toulmin Model. In D. Hitchcock, \& B. Verheij (Eds.), Arguing on the Toulmin Model: New Essays in Argument Analysis and Evaluation (pp. 203-218). Dordrecht: Springer. https://doi.org/10.1007/978-1-4020-4938-5_13

Hitchcock, D., \& Verheij, B. (2006). Introduction. In D. Hitchcock, \& B. Verheij (Eds.), Arguing on the Toulmin Model: New Essays in Argument Analysis and Evaluation (pp. 1-23). Dordrecht, The Netherlands: Springer. https://doi.org/10.1007/978-1-4020-4938-5_1

Hussain, A., Azeem, M., \& Shakoor, A. (2011). Physics Teaching Methods: Scientific Inquiry Vs Traditional Lecture. International Journal of Humanities and Social Science, 1(19), 269-276.

Hussain, M. A., Faizi, F. A., \& Rahman, F. U. (2017). Engaging Elementary School Students in Scientific Argumentation: Effectiveness and Limitations. Journal of Elementary Education, 27(1), 71-82.

Jackson, A. (2016). The latest ranking of top countries in math, reading, and science is out - and the US didn't crack the top 10. Business Insider. Retrieved May 6, 2017, from http://www.businessinsider.my/ pisa-worldwide-ranking-of-math-science-reading-skills-2016-12/?r=US\&IR=T\#xcKUJy38bKb6FTGP.97

Jiménez-Aleixandre, M. P., \& Erduran, S. (2008). Argumentation in Science Education: An Overview. In M. P. Jiménez-Aleixandre, \& S. Erduran (Eds.), Argumentation in Science Education: Perspectives from Classroom-Based Research (pp. 3-27). Dordrecht: Springer.

Johnstone, A. H. (1993). The Development of Chemistry Teaching: A changing Response to Changing Demand. Journal of Chemical Education, 70(9), 701-705. https://doi.org/10.1021/ed070p701

Johnstone, A. H. (2000). Teaching of Chemistry-Logical or Psychological? Chemistry Education: Research and Practice in Europe, 1(1), 9-15. https://doi.org/10.1039/A9RP90001B

Karbach, J. (1987). Using Toulmin's Model of Argumentation. Journal of Teaching Writing, 6(1), 81-91.

Karişan, D. (2015). Exploration of Preservice Science Teachers' Written Argumentation Skills in A. Laboratory Course: A Toulmin-Based Analysis. Ines Journal, 2(5), 247-261. https://doi.org/10.16991/INESJOURNAL.161

Kaya, E. (2013). Argumentation Practices in Classroom: Pre-service Teachers' Conceptual Understanding of Chemical Equilibrium. International Journal of Science Education, 35(7), 1139-1158. https://doi.org/10.1080/09500693.2013.770935

Kelly, R. M., Barrera, J. H., \& Mohamed, S. C. (2010). An Analysis of Undergraduate General Chemistry Students' Misconceptions of the Submicroscopic Level of Precipitation Reactions. Journal of Chemical Education, 87(1), 113-118. https://doi.org/10.1021/ed800011a

Kremer, K. D. S. (2011). Thinking Games and Activities: Making Critical Thinking Fun for the Classroom. United States of America: Lorenz Educational Press. Retrieved from https://books.google.com.my/books?isbn=1429122757

Kirbulut, Z. D., \& Beeth, M. E. (2013).Representation of Fundamental Chemistry Concepts in Relation to the Particulate Nature of Matter. International Journal of Education in Mathematics, Science and Technology, 1(2), 96-106.

Kosso, P. (2011). A Summary of Scientific Method. Dordrecht: Springer. https://doi.org/10.1007/978-94-007-1614-8

Lin, S. S., \& Mintzes, J. J. (2010). Learning Argumentation Skills through Instruction in Socioscientific Issues: The Effect of Ability Level. International Journal of Science and Mathematics Education, 8, 993-1017. https://doi.org/10.1007/s10763-010-9215-6 
Llewellyn, D. (2013). Teaching High School Science through Inquiry and Argumentation (2nd ed.). Corwin: A Sage Company.

Locker, K. O., \& Keene, M. L. (1983). Using Toulmin Logic in Business and Technical Writing Classes. In K. W. Sparrow, \& N. A. Pickett (Eds.), Technical and Business Communication in Two-Year Programs (pp. 103-109). Urbana: National Council of Teachers of English.

Maxwell, D. O. (2015). Effects of Using Inquiry-Based Learning on Science Achievement for Fifth-Grade Students. Asia-Pacific Forum on Science Learning and Teaching, 16(1), Article 2, 1-31. Retrieved from https://www.ied.edu.hk/apfslt/download/v16_issue1_files/cox.pdf

McNeill, K. L. (2011). Elementary Students' Views of Explanation, Argumentation, and Evidence, and Their Abilities to Construct Arguments over the School Year. Journal of Research in Science Teaching, 48(7), 793-823. https://doi.org/10.1002/tea.20430

Milenković, D. D., Segedinac, M. D., Hrin, T. N., \& Horvat, S. (2016). The Impact of Instructional Strategy Based on the Triplet Model of Content Representation on Elimination of Students' Misconceptions Regarding Inorganic Reactions. Journal of the Serbian Chemical Society, 81(6), 717-728. https://doi.org/10.2298/JSC150812021M

Miller, D. K. G. (2014). The Effect of Inquiry-Based, Hands-On Labs on Achievement in Middle School Science. Unpublished Bachelor's Degree Thesis. Faculty of Education, Liberty University, Lynchburg, VA. Retrieved from http://digitalcommons.liberty.edu/cgi/viewcontent.cgi?article=1938\&context=doctoral

Ministry of Education. (2012). Dasar Pendidikan Kebangsaan (Edisi Ketiga). Retrieved from http://www.moe.gov.my/userfiles/file/BUKU\%20DASAR.pdf

National Education Association (NEA). (2012). Preparing 21st Century Students for a Global Society: An Educator's Guide to the "Four Cs." Retrieved from http://www.nea.org/assets/docs/A-Guide-to-Four-Cs.pdf

National Research Council (NRC). (1996). National Science Education Standards. National Academy Press. Retrieved from https://www.csun.edu/science/ref/curriculum/reforms/nses/nses-complete.pdf

National Research Council (NRC). (2000). Inquiry and the National Science Education Standards: A Guide for Teaching and Learning. Washington D.C: National Academy Press. Retrieved from: http://www.nap.edu/download.php?record_id=9596\#

Nilgün, D. C. (2015). The Effects of Argument-Driven Inquiry Instructional Model on 10th Grade Students' Understanding of Gas Concepts. Unpublished Doctoral Degree Thesis. Faculty of Education. Middle East Technical. Retrieved from http://etd.lib.metu.edu.tr/upload/12618357/index.pdf

Njoroge, G. N., Changeiywo, J. M., \& Ndirangu, M. (2014). Effects of Inquiry-Based Teaching Approach on Secondary School Students' Achievement and Motivation in Physics in Nyeri County, Kenya. Academic Research Journals, 2(1), 1-16.

Nussbaum, E. M. (2011). Argumentation, Dialogue Theory, and Probability Modeling: Alternative Frameworks for Argumentation Research in Education. Educational Psychologist, 46(2), 84-106. https://doi.org/10.1080/00461520.2011.558816

OECD. (2016). PISA 2015 Results in Focus, PISA in Focus, No. 67. Paris: OECD Publishing. https://doi.org/10.1787/aa9237e6-en

Ogan-Bekiroglu, F., \& Eskin, H. (2012). Examination of the Relationship between Engagement in Scientific Argumentation and Conceptual Knowledge. International Journal of Science and Mathematics Education, 10, 1415-1443. https://doi.org/10.1007/s10763-012-9346-z

Opara, J. A. (2011). Inquiry Method and Student Academic Achievement in Biology: Lessons and Policy Implications. American-Eurasian Journal of Scientific Research, 6(1), 28-31.

Osborne, H. (2017, April 27). Scientists Carry Out Rat Head Transplant. Newsweek. Retrieved from http://www.newsweek.com/rat-head-transplant-sergio-canavero-xiaoping-ren-590925

Ozmen, H. (2011). Turkish Primary Students' Conceptions about the Particulate Nature of Matter. International Journal of Environmental \& Science Education, 6(1), 99-121.

Pereira, S., Santos, L., \& Lira, L. (2015). A Dialogue System for Coherent Reasoning with Inconsistent Knowledge Bases. Journal of Computer and Communications, 3, 11-19. 
https://doi.org/10.4236/jcc.2015.38002

Pollock, J. L. (1987). Defeasible Reasoning. Cognitive Science, 11, 481-518. https://doi.org/10.1207/s15516709 $\operatorname{cog} 1104 \_4$

Ponce-Espinosa, H. E., Ponce-Cruz, P., \& Molina, A. (2014). Artificial Organic Networks: Artificial Intelligence Based on Carbon Networks. Studies in Computational Intelligence. Switzerland: Springer. https://doi.org/10.1007/978-3-319-02472-1

Probosari, R. M., Ramli, M., \& Sajidan. (2016). Improving Scientific Argumentation Through The Hierarchy Of Inquiry. Proceeding of International Conference on Teacher Training and Education (ICTTE) FKIP UNS 2015, 1(1), 484-489.

Rae, W. B. (2007). The Origin of the s, p, d, f Orbital Labels. Journal of Chemical Education, 84, 757-758. https://doi.org/10.1021/ed084p757

Ragni, M., Eichhorn, C., Bock, T., Kern-Isberner, G., \& Tse, A. P. P. (2017). Formal Nonmonotonic Theories and Properties of Human Defeasible Reasoning. Minds \& Machines, 27, 79-117. https://doi.org/10.1007/s11023-016-9414-1

Riegler, A. (1998). "The End of Science": Can We Overcome Cognitive Limitations? Evolution and Cognition, $4(1), 37-50$.

Sampson, V., \& Walker, J. P. (2012). Argument-driven Inquiry as a Way to Help Undergraduate Students Write to Learn by Learning to Write in Chemistry. International Journal of Science Education, 34(10), 1443-1485. https://doi.org/10.1080/09500693.2012.667581

Schroeder, C. (1997). Knowledge and Power, Logic and Rhetoric, and Other Reflections in the Toulminian Mirror: A Critical Consideration of Stephen Toulmin's Contributions to Composition. JAC: A Journal of Composition Theory, 17(1), 95-107.

Serobatse, B. M., Selvaratnam, M., \& Drummond, H. P. (2014). Students' Conceptions about the Sub-microscopic Approach to Explanations in Chemistry throughout their BSc Degree Course. South African Journal of Chemistry, 67, 40-44.

Shemwell, J. T., \& Furtak, E. M. (2010). Science Classroom Discussion as Scientific Argumentation: A Study of Conceptually Rich (and Poor) Student Talk. Educational Assessment, 15(3), 222-250. https://doi.org/10.1080/10627197.2010.530563

Sim, J. H., \& Daniel, E. G. S. (2014). Representational Competence in Chemistry: A Comparison between Students with Different Levels of Understanding of Basic Chemical Concepts and Chemical Representations. Cogent Education, 1, 1-17. https://doi.org/10.1080/2331186X.2014.991180

Simon, S., Erduran, S., \& Osborne, J. (2006). Learning to Teach Argumentation: Research and Development in the Science Classroom. International Journal of Science Education, 28(2-3), 235-260. https://doi.org/10.1080/09500690500336957

Şimşek, P., \& Kabapinar, F. (2010). The Effects of Inquiry-Based Learning on Elementary Students' Conceptual Understanding of Matter, Scientific Process Skills and Science Attitudes. Procedia Social and Behavioral Sciences, 2, 1190-1194. https://doi.org/10.1016/j.sbspro.2010.03.170

Singh, V. (2014). Effectiveness of Inquiry Training Model for Teaching Chemistry. Scholarly Research Journal for Interdisciplinary Studies, 2(15), 2344-2349.

Sunyono, Yuanita, L., \& Ibrahim, M. (2015). Mental Models of Students on Stoichiometry Concept in Learning by Method Based on Multiple Representation. The Online J. of New Horizons in Education, 5(2), 30-45.

Suppe, F. (1998). The Structure of a Scientific Paper. Philosophy of Science, 65, 381-405. https://doi.org/10.1086/392651

Surif, J., Ibrahim, N. H., \& Dalim, S. F. (2014). Problem Solving: Algorithms and Conceptual and Open-Ended Problems in Chemistry. Procedia - Social and Behavioral Science, 116, 4955-4963. https://doi.org/10.1016/j.sbspro.2014.01.1055

Taylor, J., \& Bilbrey, J. (2012). Effectiveness of Inquiry Based and Teacher Directed Instruction in an Alabama Elementary School. Journal of Instructional Pedagogies, 8, 1-17. Retrieved from http://www.aabri.com/manuscripts/121112.pdf

Thoron, A. C., \& Myers, B. E. (2012). Effects of Inquiry-based Agriscience Instruction on Student Scientific 
Reasoning. Journal of Agricultural Education, 53(4), 156-170. https://doi.org/10.5032/jae.2012.04156

Toulmin, S. E. (1958). The Uses of Argument. Cambridge: Cambridge University Press.

Toulmin, S., Rieke, R., \& Janik, A. (1984). An Introduction to Reasoning (2nd ed.). New York: Macmillan.

Ugwuadu, O. R. (2010). The Effect of Guided Inquiry and Lecture Methods on Students' Academic Achievement in Biology. A Case Study of Yola North Local Government Area of Adamawa State. Knowledge Review, 21(1), 107-114.

Upshur, R. E. G., \& Colak, E. (2003). Argumentation and Evidence. Theoretical Medicine, 24, 283-299.

van Gijzel, B., \& Prakken, H. (2012). Relating Carneades with abstract argumentation via the ASPIC+ framework for structured argumentation. Argument and Computation, 3(1), 21-47. https://doi.org/10.1080/19462166.2012.661766

van Eemeren, F. H., Garssen, B., Krabbe, E. C. W., Snoeck Henkemans, F. A., Verheij, B., \& Wagemans, J. H. M. (2014). Handbook of Argumentation Theory. Dordrecht: Springer. https://doi.org/10.1007/978-90-481-9473-5

Venville, G. J., \& Dawson, V. M. (2010). The Impact of a Classroom Intervention on Grade 10 Students' Argumentation Skills, Informal Reasoning, and Conceptual Understanding of Science. Journal of Research in Science Teaching, 47(8), 952-977. https://doi.org/10.1002/tea.20358

Warren, J. E. (2010). Taming the Warrant in Toulmin's Model of Argument. English Journal, 99(6), 41-46.

Walker, J. P. (2011). Argumentation in Undergraduate Chemistry Laboratories (Unpublished Doctoral's Degree Thesis). Faculty of Education, School of Teacher Education. Retrieved from http://diginole.lib.fsu.edu/islandora/object/fsu:175895/datastream/PDF/view

Walker, J. P., \& Sampson, V. (2013). Learning to Argue and Arguing to Learn: Argument-Driven Inquiry as a Way to Help Undergraduate Chemistry Students Learn How to Construct Arguments and Engage in Argumentation During a Laboratory Course. Journal of Research in Science Teaching, 50(5), 561-596. https://doi.org/10.1002/tea.21082

Wild, T. A. (2012). Teacher Perceptions Regarding Teaching and Learning of Seasonal Change Concepts of Middle School Students with Visual Impairments. Journal of Science Education for Students with Disabilities, 16(1), 1-13. https://doi.org/10.14448/jsesd.05.0001

Witt, C., \& Ulmer, J. (2010). The Impact of Inquiry-Based Learning on the Academic Achievement of Middle School Students. In 2010 Western AAAE Research Conference Proceedings (pp. 269-282).

Wu, P. L., Yen, Y. R., Wu, H. J., \& Lin, C. Y. (2014). Effects of Inquiry-Based Instruction: Case Study of a Marine Technology School. The Online Journal of New Horizons in Education, 4(3), 136-140. Retrieved from http://www.tojned.net/pdf/v04i03/v04i03-19.pdf

Yakmaci-Guzel, B., \& Adadan, E. (2013). Use of Multiple Representations in Developing Preservice Chemistry Teachers' Understanding of the Structure of Matter. International Journal of Environmental \& Science Education, 8(1), 109-130.

YalçınÇelik, A., \& Kılıç, Z. (2014). The Impact of Argumentation on High School Chemistry Students' Conceptual Understanding, Attitude towards Chemistry and Argumentiveness. Eurasian Journal of Physics and Chemistry Education, 6(1), 58-75.

Zarębski, T. (2009). Toulmin's Model of Argument and the "Logic" of Scientific Discovery. Studies in Logic, Grammar and Rhetoric, 16(29), 267-283.

\section{Copyrights}

Copyright for this article is retained by the author(s), with first publication rights granted to the journal.

This is an open-access article distributed under the terms and conditions of the Creative Commons Attribution license (http://creativecommons.org/licenses/by/4.0/). 